PERSPECTIVE

\title{
Mechanosensitivity and the eye: cells coping with the pressure
}

\author{
J C H Tan, F B Kalapesi, M T Coroneo
}

Br J Ophthalmol 2006;90:383-388. doi: 10.1136/bjo.2005.079905

The cells of the various organ systems in humans are subject to mechanical forces to which they must respond. Here the authors review what is known of the ways in which the cells of animals, ranging from the prokaryotic to humans, sense and transduce mechanical forces to respond to such stimuli. In what way this pertains to the eye, especially with respect to axial myopia and the pressure related disease of glaucoma, is then surveyed.

See end of article for authors' affiliations

......................

Correspondence to: Professor Minas T Coroneo, Department of

Ophthalmology, Prince of Wales Hospital, High Street, Randwick, NSW 2032, Australia; m.coroneo@unsw.edu.au

Accepted for publication 1 November 2005
E arly laboratory studies of the biological consequences of extreme hydrostatic pressure were inspired by deep sea exploration, chief of which was the Talisman dredging expedition in the 19th century, in which various baroduric or barophilic organisms were found living in depths exceeding 6000 metres under pressures of more than 600 atmospheres $\left(4.6 \times 10^{5} \mathrm{~mm} \mathrm{Hg} ; \quad 1\right.$ atm $\left.=760 \mathrm{~mm} \mathrm{Hg}\right)$. It is estimated that over half the earth's biosphere by area and nearly $90 \%$ of the seabed is under at least $1 \mathrm{~km}$ of water and pressures exceeding 100 atm. The Marianas Trench, the deepest known part of our oceans, is over 11000 metres deep with its floor under at least $1100 \mathrm{~atm}$ pressure. Entire ecosystems exist in these places ${ }^{1}$ and organisms living here must be able to survive under pressure.

Our own cells, singly or in tissues, are subject to mechanical forces that, though nowhere as extreme as at the ocean bed, must be responded and adapted to. Forces are exerted on the cell from without-hydrostatic pressure, tension, compression (squeezing), torsion (twisting), vibration, shear and stretch (tensile stress) that can deform the cell-and from within, such as changes in osmotic pressure and swelling. By this the cell receives vital information about its physical world.

It stands to reason that if such stresses are excessive or not responded to optimally, they may damage cells, cause disease, and even kill the organism. How do cells detect mechanical changes in their environment and signal responses? What is the nature of such responses? Cells of our various body systems - for example, heart and blood vessel, lung, kidney, bone, neurological and eye, are constantly subjected to forces which may well overwhelm their capacity to respond accordingly. What events transpire when this happens? Are damaged cells able to repair themselves? It is certainly possible that some basic mechanisms mediating sensitivity to mechanical forces are common to cells across different organ systems, and indeed even across different species.

For a cell to be mechanosensitive it must be able to respond to forces acting within its immediate vicinity. The sensing of these forces and conversion into signals that promote a response is termed mechanotransduction. Aortic endothelial cells elongate and their long axis and microtubules align perpendicular to flow induced shear stress ${ }^{2}$; aortic smooth muscles, ${ }^{3}$ cardiac myocytes, ${ }^{4}$ and skin and scar fibroblasts ${ }^{5}$ orientate perpendicular to the direction of stress; when strained, arterial smooth muscles develop more prominent actin cables and lay down extracellular matrix (ECM) proteoglycans ${ }^{6}$; intermittently stretched skeletal muscles bearing static loads increase protein and collagen synthesis and prostaglandin $\mathrm{F}$ $(\text { PGF- } 2 \alpha)^{78}$; new bone formation occurs after a load cycle ${ }^{9}$ and osteoblasts produce more PGE-2 and $\mathrm{CAMP}^{10}$; lung type II alveolar cells, when stretched, release more surfactant and phosphotidylcholine, surfactant's major component $t^{11}$; cardiac and skeletal muscle mass are affected by external load in vivo ${ }^{12}$; when the median nerve is subjected to pressures of $30 \mathrm{~mm} \mathrm{Hg}$ or more in carpal tunnel syndrome, its nerve cell bodies and axonal transport are altered ${ }^{13}{ }^{14}$; trabecular meshwork (TM) cells express the protein myocilin in response to stretch and raised hydrostatic pressure. ${ }^{15}$ Some cells mediating sensation are specialised for mechanotransduction: minute deflections of auditory hair cells are transduced into signals that allow us to hear, and pacinian receptors in the skin transduce pressure into electrical signals. Other specialised baroreceptor cells in the myocardium, arteries, and kidney have a feedback role on cardiac load, serum osmolarity, and blood pressure to allow physiological regulation.

Much fundamental research has sought to define the cellular mechanisms mediating mechanosensitivity. One such mechanism implicates membrane bound mechanically gated channels which are sensitive, speedy in response, and allow huge ion influxes and amplified signals. Yet another mechanism is the coupled

Abbreviations: BDNF, brain derived neurotrophic factor; cAMP, cyclic adenosine monophosphate; DAG, diacyl glycerol; ECM, extracellular matrix; EGF, epidermal growth factor; IOP, intraocular pressure; IP3, inositol-3phosphate; MAP-kinase, mitogen activated protein kinase; MMPs, matrix metalloproteinases; PDGF, platelet derived growth factor; $\mathrm{PGF}$, prostaglandin $\mathrm{F}$; PKA, protein kinase A; PKC, protein kinase C; RGC, retinal ganglion cells; TIMP, tissue inhibitor of MMP; TM, trabecular meshwork; VEGF, vascular endothelium growth factor 
and interconnected cytoskeleton-ECM complex (see fig 1), which has critical roles in intracellular signalling. ${ }^{16}$ Mechanisms underlying mechanosensitivity in animals ranging from unicellular prokaryotes to invertebrates to humans have been described and we have sought to survey this body of information in a way that is relevant to the eye.

\section{MECHANICALLY GATED ION CHANNELS}

Mechanically gated channels open when the cell membrane receives stimuli such as stretch, shear, and displacement. Some channels are permeable to anions (for example, $\mathrm{Cl}^{-}$) while others are permeable to cations (for example, $\mathrm{Ca}^{2+}$, $\left.\mathrm{K}^{+}\right) .{ }^{17}$ These channels are the most widely studied mechanosensitive structures in cell membranes. They were first conceived in whole cell studies of specialised mechanosensory neurons, ${ }^{18}{ }^{19}$ but first discovered by patch clamping in cultured chick skeletal muscle ${ }^{20}$ at almost the same time as their discovery in embryonic Xenopus muscle. ${ }^{21}$ They have now been identified in many cell types including those within the eye.

Bacteria mostly have rigid cell walls that protect them from excessive swelling and deformation, although this also renders them less sensitive to mechanical stimuli. How bacteria might respond to external forces has been suggested by the discovery and cloning of mechanically gated channels in Escherichia coli ${ }^{22-24}$ and subsequently other bacteria, both Gram positive and negative having different cell wall structures. ${ }^{25-27}$ A class of $E$ coli receptors called MscL are postulated to protect the bacterium from osmotic damage as they open just below pressures that would otherwise disrupt the bacterial cell membrane. Mechanically gated channels have also been demonstrated in archea, ${ }^{28}{ }^{29}$ the other major domain of the phylogenetic tree. These micro-organisms live in harsh environments such as extremely hot ocean hydrothermal vents or the salty Dead Sea. The mechanically gated channels of prokaryotes are generally activated by high tensions, have high ion conductance, and lack ionic specificity when compared with those of eukaryotes. It is known however that genetically mutating prokaryotic channels can confer upon them the gating characteristics of eukaryotic channels. ${ }^{30}$
Eukaryotic cells lack rigid walls but their plasma membranes are internally supported by an elaborate cytoskeleton. The actin cytoskeleton resists membrane deformability, while providing internal scaffolding for linking or tethering various proteins such as signalling molecules and mechanosensitive channels. Disrupting actin increases the conductance of mechanosensitive channels. ${ }^{31}$ The actin cytoskeleton is a dynamic structure that constantly rearranges itself and is interconnected with the ECM and cytoskeleton of adjacent cells by specialised membrane bound proteins. Any changes in the cytoskeleton, plasma membrane and ECM might thus be expected to influence the mechanically gated channels.

Mechanically gated channels have been identified in diverse cells. ${ }^{32}$ There are several classes of channels, many of which are permeable to cations, not uncommonly $\mathrm{Ca}^{2+}$, a ubiquitous intracellular messenger. $\mathrm{Ca}^{2+}$ rushing into the cell can itself induce $\mathrm{Ca}^{2+}$ release from internal stores and trigger molecular switches such as protein kinase C (PKC) which in turn phosphorylates target and gene regulatory proteins. For instance, bending of auditory hair cells opens a non-selective mechanically gated cation channel that depolarises the cell and activates voltage sensitive $\mathrm{Ca}^{2+}$ channels to induce synaptic vesicle exocytosis. ${ }^{33}{ }^{34}$ A recently identified family of channels with weak inwardly rectifying $\mathrm{K}+$ conductance $^{35-37}$ includes TREK-1 and TRAAK, which are found widely in brain and spinal cord. ${ }^{38}$ In vitro, TREK-1 is sensitive to suction and osmotic swelling and shrinkage. TRAAK is sensitive to suction and pressure but also to arachidonic acid. It is present in the retina in ganglion cells, amacrine, horizontal and rod bipolar cells, and outer segments of photoreceptors. ${ }^{38-40}$

Sensory elements showing specific responses to mechanical stimulation have been identified in the cornea of rabbits, and cornea, sclera, bulbar conjunctiva, and uvea of cats. ${ }^{41}{ }^{42}$ Mammalian corneal epithelium, non-pigmented ciliary epithelium, and TM cells also have volume regulated outwardly rectifying chloride channels which respond to hypotonic cellular swelling and potentially help maintain the clarity of the ocular media and the secretion and outflow of the aqueous humour. ${ }^{43-48}$

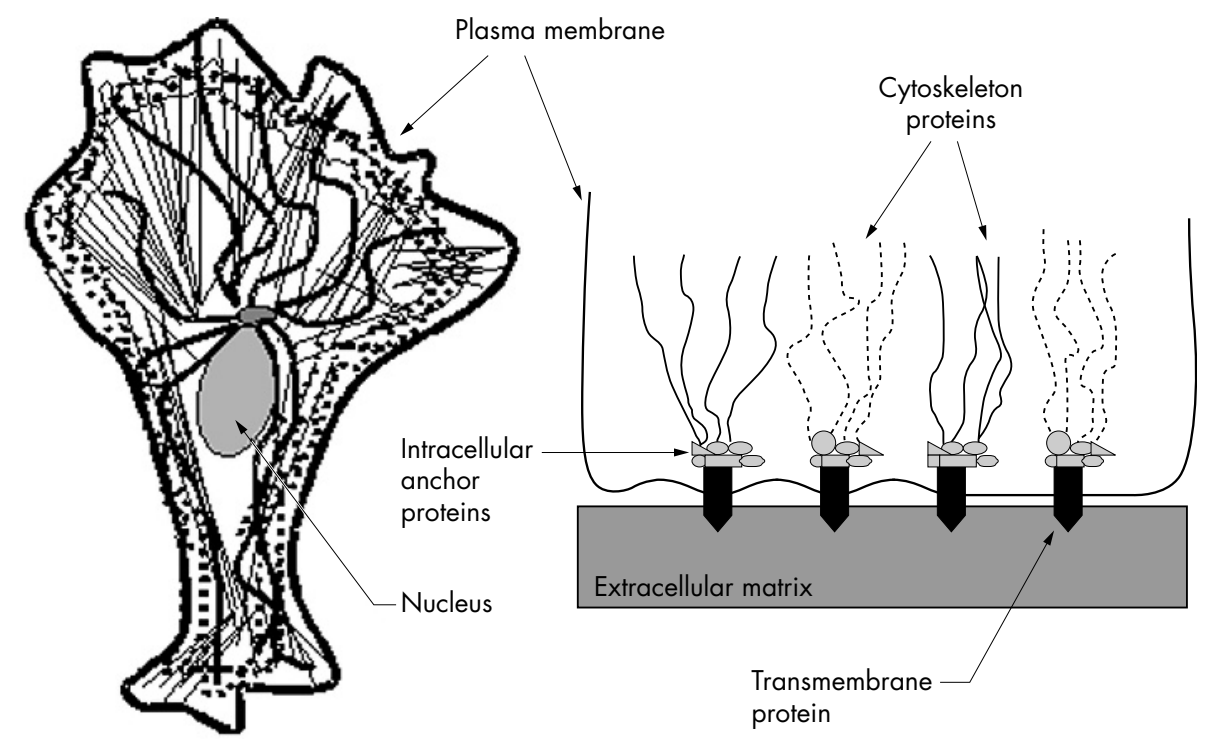

Figure 1 The cell cytoskeleton (left) and its relation to cell-extracellular matrix adhesions (right). (Left) The cytoskeleton consists of three main proteins: actin microfilaments (thin lines), microtubules (bold wavy lines), and intermediate filaments (dotted lines). Microtubules meet at the centromere next to the nucleus. (Right) The family of integrins are important transmembrane proteins that anchor the cell to the extracellular matrix. Cell-matrix contacts are called focal adhesions if they connect with actin microfilaments intracellularly, and hemidesmosomes if they connect with intermediate filaments. Integrins link with actin via various proteins such as talin, $\alpha$-actinin, and filamin at focal adhesion complexes. 


\section{TRANSMISSION OF FORCES BETWEEN THE CYTOSKELETON AND EXTRACELLULAR MATRIX}

The eukaryotic cell can be thought of as a physical structure in which mechanical stresses are distributed across its interconnected elements. ${ }^{49} 50$ The integration and coupling of the cell cytoskeleton to its plasma membrane (and its channels), the ECM via focal adhesions, and adjacent cells by cell-cell contacts such as adherens junctions provides a means for mediating mechanosensitvity and transduction.

The main cytoskeletal proteins are actin, intermediate filaments, and microtubules. Actin filaments, which determine cell shape and movement, are distributed throughout the cell, though especially just beneath the plasma membrane as the cortical cytoskeleton. Intermediate filaments are the cell's cable scaffolding. They give it mechanical strength, help it withstand shear stress, and assist with motility. Microtubules direct intracellular traffic and determine where organelles lie. Integrins are membrane spanning proteins that help cells grip their ECM at sites called focal adhesions (for actin) or hemidesmosomes (for intermediate filaments). Integrin intracellular domains link to the cytoskeleton by proteins such as talin, $\boldsymbol{\alpha}$-actinin, and filamin as well as many other intervening proteins, as illustrated in figure 1. The cytoskeleton is linked to adjacent cells at cell-cell junctions via other intervening proteins such as cadherin. These linkages facilitate the forming of an interconnected structural unit, allowing concerted regulation of cell shape, orientation and movement, ${ }^{49} 50$ and ECM organisation. ${ }^{51} 52$

The cytoskeleton imparts rigidity to cells and the fluid membrane bilayer and helps the cell withstand deforming forces and shear stress. Having this internal scaffolding means that eukaryotic cells do not need rigid walls, can receive feedback from their physical surroundings, and are able to assume non-spherical shapes. For example, microvilli can stably maintain excess plasma membrane to increase surface area, and better cope with intracellular volume changes; erythrocytes are concave and have 40\% extra membrane surface area than if they were spherical, allowing volume increases to be easily accommodated. ${ }^{30}$ The erythrocyte's interconnected cortical cytoskeleton of spectrin actin tropomyosin is somewhat "coiled" at rest, permitting structural expansion as needed. ${ }^{53}$ Such variation in membrane curvature, surface area and tension might also be expected to influence the characteristics and gating of mechanosensitive channels. The Rho family of small GTPases, comprising signalling proteins such as Rho, Rac, and Cdc42, has a particularly vital role in regulating the response of cytoskeletal and cell contacts to mechanical forces.

\section{PLASMA MEMBRANE MECHANOTRANSDUCTION AND REPAIR}

The plasma membrane encapsulates the cell, is relatively impermeable to water soluble molecules, and maintains its internal environment as different from outside. It is a fluid, continuous lipid bilayer held together by non-covalent forces. Proteins embedded in or spanning the membrane are responsible for nearly all its functions: ionic and molecular transport, catalysing reactions, acting as receptors for signal transduction, and linking the membrane to the cytoskeleton, ECM, and adjacent cells. Each has a postulated role in mechanotransduction. For example, stretching the plasma membrane can activate several membrane bound intracellular signalling proteins such as receptor tyrosine kinases and $\mathrm{G}$ proteins, phospholipase $\mathrm{C}$ and phospholipase A2, the inositol phospholipid signalling pathway (via IP3 and $\mathrm{Ca}^{2+}$ ), eicosanoids (via DAG and PKC), and cAMP (via PKA). Stretched lung alveolar epithelial cells activate Gproteins and MAP kinase pathways ${ }^{52}$; mechanically stressed osteocytes in culture increase PGE- 2 by $\mathrm{Ca}^{2+}$ and cytoskeleton mediated mechanisms. ${ }^{54}$

Cells have mechanisms to repair or reseal mechanically damaged or ruptured membranes. ${ }^{55}$ It is proposed that both the fusion of endocytotic vesicles, a slow process taking minutes to hours, and exocytosis taking seconds can help plasma membranes reseal by incorporating freshly recruited vesicular membrane. ${ }^{56}{ }^{57}$ Both are triggered by high intracellular $\mathrm{Ca}^{2+}$ concentrations and are under the regulation of the Rho family of GTPases. Fused larger vesicles traffic from the Golgi apparatus along microtubules towards the plasma membrane where bursts of exocytosis seal punctures. ${ }^{55}$ Cytochalasin D affects actin polymerisation and appears to promote resealing possibly because it reduces membrane tension. $^{58}$ In erythrocytes, the spectrin network facilitates membrane healing after the plasma membrane is ruptured mechanically. ${ }^{59}$

\section{LIFE AND DEATH AFTER MECHANICAL STRESS}

Cells can be injured and die if mechanical stresses become overwhelming. Disruption of the plasma membrane can cause influx of ions and alter cell osmolarity and volume, affecting ionic gradients, membrane potential, and the functioning of membrane proteins such as channels. Mechanically gated channels, by permitting $\mathrm{Ca}^{2+}$ influx, can elevate intracellular $\left[\mathrm{Ca}^{2+}\right]$ and stimulate further $\mathrm{Ca}^{2+}$ release from cytoplasmic stores. Outward pumping of $\mathrm{Ca}^{2+}$ may be impeded if other membrane proteins stop working. Changes in intracellular $\left[\mathrm{Ca}^{2+}\right]$ are needed for cell growth, differentiation, movement, intracellular signalling and synaptic transmission, but too much $\mathrm{Ca}^{2+}$ can cause necrosis and apoptosis. Necrotic cells swell and burst, but in apoptosis-a tightly regulated programme of cell death-the cell shrinks, its cytoskeleton involutes, nuclear envelope dismantles, nuclear DNA fragments and surface alters, inviting phagocytosis.

Cells usually need to be attached to underlying ECM to grow, divide, and survive, and these activities are modulated by various influences such as biochemical activity at cellECM adhesions and growth factors. Growth factors, by binding to cell surface receptors, can activate growth promoting second messengers, while some also promote mitogenesis. Examples of growth factors, which various cells have been shown to secrete when their substrata are mechanically stretched in vitro, are PDGF, EGF and VEGF (for example, fetal lung (PDGF), smooth muscles (EGF), and retinal pigment epithelium (VEGF)).$^{60}$

\section{AXIAL MYOPIA, A MODEL OF OCULAR "BAROPATHY"}

The development of high myopia is associated with axial elongation, primarily as a result of deepening of the vitreous chamber. ${ }^{61}$ Axial elongation in myopic eyes is associated with scleral remodelling which causes marked thinning of the sclera especially at the posterior pole. Loss of scleral tissue and scleral weakening precipitates local ectasic change or posterior staphylomata may form. ${ }^{61-63}$ The altered scleral morphology is associated with changed collagen fibril ultrastructure, greater numbers of small diameter collagen fibrils, and a more lamellar arrangement of collagen fibril bundles in the posterior sclera. ${ }^{64}$ Myopic scleral remodelling also results in reduced glycosaminoglycan and collagen content. ${ }^{65}$ These changes reduce scleral resistance to expansion in response to a range of intraocular pressures (IOP), resulting in axial lengthening.

A study by Phillips et $a^{l^{6}}$ suggests that the presence of specialised contractile fibroblasts called myofibroblasts protects against the development of axial myopia. In this study, IOP was experimentally raised in both chick and tree shrew eyes. On normalising IOP, the chick but not the tree shrew 
eye showed residual axial elongation as only the tree shrew was able to recover from the induced axial myopia. Tree shrew eyes were found by immunohistchemistry to have myofibroblasts within the sclera and choroid, but chick eyes had myofibroblasts only in the choroid. ${ }^{6}$ It has been proposed that myofibroblasts work as an interlinked syncytium to both sense and respond to changes in their mechanical environment, providing a mechanotransduction pathway that helps maintain ocular structure. It is probably by contractile myofibroblasts responding to altered forcelength relations within the scleral ECM that the tree shrew is able to restore vitreous chamber depth. ${ }^{69}$ Scleral fibroblasts are known to produce matrix metalloproteases (MMPs), which further contribute to scleral remodelling. ${ }^{67}$

At the gene expression level, microarray studies of human scleral fibroblasts show differential changes in gene expression after short (30 minutes) and longer (24 hours) durations of stretching. Genes found to be significantly upregulated code for cell receptors, protein kinases, cell growth/differentiation factors, ECM proteins, lipid and protein metabolism, transcription factors and water channels, and could be involved in the scleral remodelling occurring during axial myopia. ${ }^{68}$

\section{GLAUCOMA, ANOTHER OCULAR "BAROPATHY"}

Glaucoma is an optic neuropathy that has as its basis slowly progressive loss of retinal ganglion cells (RGC) and their axons, and as a major risk factor, IOP. At least some RGC death in glaucoma occurs by apoptosis, ${ }^{69-71}$ which may be a mechanism by which putative insults such as elevated hydrostatic pressure, ${ }^{72}{ }^{73}$ glutamate neurotoxicity, ${ }^{9}{ }^{74}{ }^{75}$ neurotrophic deprivation, ${ }^{76}$ autoimmunity, ${ }^{77}$ nitric oxide, ${ }^{78}$ and intracellular calcium toxicity and ischaemia cause RGC death.

Several lines of evidence implicate the optic nerve head's lamina cribrosa, where axons exit the eye, as the primary site of RGC damage leading to death. ${ }^{79-81}$ Quigley et al' $\mathrm{s}^{82}$ human postmortem studies point to the cribriform plates of glaucoma eyes becoming compressed with disease, then collapsing and bowing posteriorly. Similar changes are seen in primate models of glaucoma. ${ }^{83}$ Experimental studies show that slow and rapid axonal transport can get blocked at the lamina cribrosa with raised IOP, ${ }^{79808485}$ possibly affecting the transport and availability of trophic factors such as BDNF which ganglion cells need to survive. ${ }^{85}$ This indicates that mechanical changes at the lamina cribrosa physically impinge on and injure RGCs, depriving nerve cells of structural and nutritional support and promoting apoptosis.

Some in vitro evidence also supports the possibility that RGCs and astroglia may themselves be directly affected by elevated hydrostatic pressure. Apoptosis is increased in cultured RGCs and other central nervous system cells subjected to hydrostatic pressures mimicking conditions in acute $(100 \mathrm{~mm} \mathrm{Hg})$ and chronic $(30 \mathrm{~mm} \mathrm{Hg})$ glaucoma. In these experiments, higher pressures were associated with more apoptosis. ${ }^{72} 7386$ Cultured lamina cribrosa astroglia, when exposed to raised hydrostatic pressure, release tumour necrosis factor $\alpha$ and nitric oxide, both pro-apoptotic substances; if RGCs are co-incubated with these pressurised glia, the RGCs undergo apoptosis. ${ }^{87}$ In vivo, retinal atrocytes upregulate glial fibrillary acid protein expression when IOP is raised $^{88}$; the caspase cascade has been implicated in RGC death following exposure to raised hydrostatic pressure. ${ }^{88}$ TRAAK, the mechanically gated $\mathrm{K}^{+}$channel, which is also opened by pressure, membrane stretch and arachidonic acid, and blocked by gadolinium, is found in the cell bodies and axons of RGCs. In vitro, treating RGCs with arachidonic acid to open TRAAK channels causes apoptosis, ${ }^{89}$ suggesting the possibility that such mechanically gated channels have a role in neuronal death caused by pressure.

Elevated IOP is implicated in glaucomatous optic neuropathy. IOP is determined by the equilibration of aqueous humour production by the ciliary body and aqueous outflow by the TM and uveoscleral pathways. Stretched cultured TM cells are reported to elongate and rearrange their actin, phosphorylate paxillin in focal adhesion complexes, and activate tyrosine phosphorylation and MAP kinase signalling. ${ }^{90}$ High conductance $\mathrm{Ca}^{2+}$ activated $\mathrm{K}^{+}$channels are activated when cultured TM cells are stretched or undergo volume changes. ${ }^{11}$ When exposed to elevated hydrostatic pressure, cells from pigmented and non-pigmented ciliary epithelium and the TM become rounder, their processes retract, actin filaments are displaced mainly to the periphery of the cytoplasm, and adenylyl cyclase activity is increased ${ }^{92}$; stretched TM cells upregulate genes controlling inflammation, secretion, ECM digestion, cell responses to oxidative stress, and cytoskeleton organisation ${ }^{93}$; stretch decreases levels of $\alpha \mathrm{B}$-crystallin, which has a possible role in stabilising and regulating actin; ${ }^{94}$ phacoemulsification ultrasound vibration induces signal transduction in TM cells in vitro ${ }^{95}$; stretched cultured TM cells alter their secretion of MMPs and their inhibitors, suggesting that ECM turnover is altered and apparently influences fluid outflow through the TM. ${ }^{96}$ Mechanosensors are thought to be present at the scleral spur and might serve as a form of regulatory feedback. ${ }^{97}$ In the TM, myocilin expression is upregulated and its secretion increased with raised hydrostatic pressure and stretch. ${ }^{15} 939899$ In vivo, the TM is itself in a contracted state, which if relaxed can dramatically increase aqueous outflow. ${ }^{100-102}$

TM cells subjected to mechanical strain/stretching show increased production of MMPs. ${ }^{103-105}$ Mechanically strained bovine TM cells show increased stromelysin and gelatinase A activity, which is reversible with relaxation of mechanical stretch. ${ }^{104}$ Stretched TM increases production of MMP-2 and MMP-14 while reducing levels of the tissue inhibitor of MMP (TIMP-2). ${ }^{103-105}$ Pressure induced alterations in MMP activity with resultant ECM degredation may affect TM outflow resistance and have an important role in IOP regulation.

Taken together, these findings indicate that cells within the outflow pathways exhibit features of mechanosensitivity which may well provide them with the means to respond to physical changes in their environment.

\section{CONCLUSIONS}

It appears that cells have a repertoire of strategies for dealing with mechanical stimuli. Many of these strategies are common to the cells of different mammalian tissues and some are universal to a wide range of living organisms. Several appear relevant to the eye and to the way ocular cells respond to their physical environment in health and disease.

\section{ACKNOWLEDGEMENTS}

Dr Tan's contribution was supported by a research grant from the University of New South Wales Medical School in Sydney, Australia. Dr Kalapesi is a recipient of a NHMRC scholarship, Australia. Professor Coroneo's cited research was supported by grants from the Ophthalmic Research Institute of Australia and Allergan. The authors have no competing interests to declare.

\section{Authors' affiliations}

J C H Tan, F B Kalapesi, M T Coroneo, Department of Ophthalmology, Prince of Wales Hospital, University of New South Wales, Sydney, Australia

J C H Tan, Department of Ophthalmology and Visual Science, University of Wisconsin-Madison, WI, USA 


\section{REFERENCES}

1 Ashcroft F. Life at the extremes. The science of survival. London: HarperCollins, 2000.

2 Ives CL, Eskin SG, Mclntire LV. Mechanical effects on endothelial cell morphology: in vitro assessment. In Vitro Cell Dev Biol 1986;22:500-7.

3 Dartsch PC, Hammerle $\mathrm{H}$. Orientation response of arterial smooth muscle cells to mechanical stimulation. Eur J Cell Biol 1986;41:339-46.

4 Terracio L, Miller B, Borg TK. Effects of cyclic mechanical stimulation of the cellular components of the heart: in vitro. In Vitro Cell Dev Biol 1988;24:53-8.

5 Henderson R, Banes A, Solomon G, et al. Human scar fibroblasts react to applied tension in vitro by aligning and increasing polymerised actin content. FASEB J 1988;2:A574.

6 Leung DY, Glagov S, Mathews MB. Cyclic stretching stimulates synthesis of matrix components by arterial smooth muscle cells in vitro. Science 1976;191:475-7.

7 Vandenburgh $\mathbf{H}$, Kaufman S. In vitro model for stretch-induced hypertrophy of skeletal muscle. Science 1979;203:265-8.

8 Palmer RM, Reeds PJ, Lobley GE, et al. The effect of intermittent changes in tension on protein and collagen synthesis in isolated rabbit muscles. Biochem J 1981;198:491-8.

9 Skerry TM, Bitensky L, Chayen J, et al. Loading-related reorientation of bone proteoglycan in vivo. Strain memory in bone tissue? J Orthop Res 1988;6:547-51

10 Somjen D, Binderman I, Berger $E$, et al. Bone remodelling induced by physical stress is prostaglandin E2 mediated. Biochem Biophys Acta 1988;627:91-100.

11 Wirtz HR, Dobbs LG. Calcium mobilization and exocytosis after one mechanical stretch of lung epithelial cells. Science 1990;250:1266-9.

12 Morgan HE, Baker KM. Cardiac hypertrophy. Mechanical, neural, and endocrine dependence. Circulation 1991;83:13-25.

13 Dahlin LB, Nordborg C, Lundborg G. Nerve cell body changes and nerve compression. Exp Neurol 1987;95:61 1-21.

14 Gelberman RH, Hergenroeder AR, Hargens AR, et al. The carpal tunnel syndrome-a study of carpal tunnel pressure. J Bone Joint Surg $1981 ; 63: 380-3$.

15 Tamm ER, Russell P, Epstein DL, et al. Modulation of myocilin/TIGR expression in human trabecular meshwork. Invest Ophthalmol Vis Sci 1999:40:2577-82.

16 Geiger B, Bershadsky A. Exploring the neighborhood: adhesion-coupled cell mechanosensors. Cell 2002;110:139-42.

17 Morris CE. Mechanosensitive ion channels. J Membr Biol 1990; 1 13:93-107.

18 Katz B. Depolarisation of sensory terminals and the initiation of impulses in the muscle spindle. J Physiol (Lond) 1950;111:261-82.

19 Loewenstein WR. The generation of electric activity in a nerve ending. Ann NY Acad Sci 1959;81:367-87.

20 Guharay F, Sachs F. Stretch-activated single ion channel currents in tissuecultured embryonic chick skeletal muscle. J Physiol 1984;352:685-701.

21 Brehm P, Kullberg R, Moody-Corbett F. Properties of non-junctional acetylcholine receptor channels on innervated muscle of Xenopus laevis. J Physiol 1984;350:631-48.

22 Martinac B, Buechner M, Delcour AH, et al. Pressure-sensitive ion channel in Escherichia coli. Proc Natl Acad Sci USA 1987;84:2297-301.

23 Sukharev SI, Blount P, Martinac B, et al. A large-conductance mechanosensitive channel in $\mathrm{E}$. coli encoded by MscL alone. Nature 1994;368:265-8.

24 Sukharev SI, Blount P, Martinac B, et al. Mechanosensitive channels of Escherichia coli: the MscL gene, protein, and activities. Annu Rev Physiol 1997; 59:633-57.

25 Blount P, Moe PC. Bacterial mechanosensitive channels: integrating physiology, structure and function. Trends Microbiol 1999;7:420-4.

26 Zoratti M, Petronilli V. lon-conducting channels in a gram-positive bacterium. FEBS Lett 1988;240:105-9.

27 Zoratti M, Petronilli V, Szabo I. Stretch-activated composite ion channels in Bacillus subtilis. Biochem Biophys Res Commun 1990;168:443-50.

28 Le Dain AC, Saint N, Kloda A, et al. Mechanosensitive ion channels of the archaeon Haloferax volcanii. J Biol Chem 1998;273:12116-19.

29 Kloda A, Martinac B. Molecular identification of a mechanosensitive channel in archaea. Biophys J 2001;80:229-40.

30 Hamill OP, Martinac B. Molecular basis of mechanotransduction in living cells. Physiol Rev 2001;81:685-740.

31 Wan X, Juranka P, Morris CE. Activation of mechanosensitive currents in traumatized membrane. Am J Physiol 1999;276:C318-27.

32 Sachs F. Mechanical transduction in biological systems. Crit Rev Biomed Eng 1988;16:141-69

33 Assad JA, Shepherd GM, Corey DP. Tip-link integrity and mechanical transduction in vertebrate hair cells. Neuron 1991;7:985-94.

34 Marquis RE, Hudspeth AJ. Effects of extracellular Ca2+ concentration on hair-bundle stiffness and gating-spring integrity in hair cells. Proc Natl Acad Sci USA 1997;94:11923-8.

35 Lesage F, Guillemare E, Fink $M$, et al. TWIK-1, a ubiquitous human weakly inward rectifying $\mathrm{K}+$ channel with a novel structure. $E M B O J$ 1996;15:1004-11.

36 Maingret $F$, Fosset $M$, Lesage $F$, et al. TRAAK is a mammalian neuronal mechano-gated K+ channel. J Biol Chem 1999;274:1381-7.

37 Patel AJ, Honore E, Maingret F, et al. A mammalian two pore domain mechano-gated S-like K+ channel. EMBO J 1998;17:4283-90.

38 Patel AJ, Lazdunski M, Honore E. Lipid and mechano-gated 2P domain $\mathrm{K}(+)$ channels. Curr Opin Cell Biol 2001;13:422-8.
39 Fink $M$, Lesage $F$, Duprat $F$, et al. A neuronal two $P$ domain $K+$ channel stimulated by arachidonic acid and polyunsaturated fatty acids. EMBO J 1998; 17:3297-308

40 Reyes $\mathbf{R}$, Lauritzen I, Lesage $F$, et al. Immunolocalization of the arachidonic acid and mechanosensitive baseline traak potassium channel in the nervous system. Neuroscience 2000;95:893-901.

41 Belmonte C, Garcia-Hirschfeld J, Gallar J. Neurobiology of ocular pain. Progr Retinal Eye Res 1997;16:117-56.

42 Mintenig GM, Sanchez-Vives MV, Martin C, et al. Sensory receptors in the anterior uvea of the cat's eye. Invest Ophthalmol Vis Sci 1995;36:1615-24.

43 Al-Nakkrash L, Iserovich P, Coca-Prados M, et al. Functional and molecular characterization of a volume-activated chloride channel in rabbit corneal epithelial cells. J Membrane Biol 2004;201:41-9.

44 Do CW, Lu W, Mitchell CH, et al. Inhibition of swelling-acivated $\mathrm{Cl}^{-}$currents by functional anti-CLC-3 antibody in native bovine non-pigmented ciliary epithelial cells. Invest Ophthalmol Vis Sci 2005;46:948-55.

45 Srinivas SP, Maertens C, Goon LH, et al. Cell volume response to hyposmotic shock and elevated cAMP in bovine trabecular meshwork cells. Exp Eye Res 2004;78:15-26

46 Soto D, Comes N, Ferrer E, et al. Modulation of aqueous humor outflow by ionic mechanisms involved in trabecular meshwork cell volume regulation. Invest Ophthalmol Vis Sci 2004;45:3650-61

47 Mitchell CH. Fleischhaver JC, Stamer D, et al. Human trabecular meshwork cell volume regulation. Am J Physiol Cell Physiol 2002;283:C315-26.

48 Comes N, Gassull X, Gual A, et al. Differential expression of the human chloride channel genes in the trabecular meshwork under stress conditions. Exp Eye Res 2005;80:801-13.

49 Ingber DE. Cellular tensegrity: defining new rules of biological design that govern the cytoskeleton. J Cell Sci 1993;104:613-27.

50 Ingber DE. Tensegrity: the architectural basis of cellular mechanotransduction. Annu Rev Physiol 1997;59:575-99.

51 Pelham RJ, Wang Y-L. Cell locomotion and focal adhesions are regulated by substrate flexibility. Proc Natl Acad Sci USA 1997:94:13661-865.

52 Choquet D, Felsenfeld DP, Sheetz MP. Extracellular matrix rigidity causes strengthening of integrin-cytoskeleton linkages. Cell 1997;88:39-48.

53 Mohandas N, Evans E. Mechanical properties of the red cell membrane in relation to molecular structure and genetic defects. Annu Rev Biophys Biomol Struct 1994;23:787-818

54 Ajubi NE, Klein-Nulend J, Alblas MJ, et al. Signal transduction pathways involved in fluid flow-induced PGE2 production by cultured osteocytes. Am J Physiol 1999;276:E171-8.

55 Steinhardt RA, Bi G, Alderton JM. Cell membrane resealing by a vesicular mechanism similar to neurotransmitter release. Science 1994;263:390-3.

56 Terasaki M, Miyake K, McNeil PL. Large plasma membrane disruptions are rapidly resealed by $\mathrm{Ca} 2+-$ dependent vesicle-vesicle fusion events. J Cell Biol 1997; 139:63-74

$57 \mathrm{Bi} \mathrm{GQ}$, Alderton JM, Steinhardt RA. Calcium-regulated exocytosis is required for cell membrane resealing. J Cell Biol 1995; 131:1747-58.

58 Togo $\mathrm{T}$, Alderton JM, Bi GQ, et al. The mechanism of facilitated cell membrane resealing. J Cell Sci 1999;112:719-31.

59 Baumann M, Grebe R. Characteristics of the osmotically induced membrane rupture. Mol Membr Biol 1998;15:193-201.

60 Apodaca G. Modulation of membrane traffic by mechanical stimuli. Am J Physiol Renal Physiol 2002;282:F179-90.

61 McBrien NA, Gentle A. Role of the sclera in the development and pathological complications of myopia. Progr Retinal Eye Res 2003;22:307-38.

62 Curtin BJ, Teng CC. Scleral changes in pathological myopia. Trans Am Ophthalmol Soc 1958;62:777-8.

63 Curtin BJ. The posterior staphyloma of pathologic myopia. Trans Am Ophthalmol Soc 1977;75:67-86.

64 Curtin BJ, Iwamoto T. Normal and staphylomatous sclera of high myopia. An electron microscopic study. Arch Ophthalmol 1979;97:912-5.

65 Avetisov ES, Savitskaya NF. A study of biochemical and biomechanical qualities of normal and myopic eye sclera in humans of different age groups. Metabol Pediatr Systemic Ophthalmol 1983;7:183-8.

66 Phillips JR, McBrien NA. Pressure-induced changes in axial eye length of chick and tree shrew: significance of myofibroblasts in the sclera. Invest Ophthalmol Vis Sci 2004:45:758-63.

67 Wei CP, McDonnell PJ, Bryant MR. Integrin mediated the stretch-induced expression of genes for MMP-1 and MMP-2 in fetal human scleral fibroblasts. Invest Ophthalmol Vis Sci 2001;42:S660.

68 Cui W, Bryant MR, Sweet PM, et al. Changes in gene expression in response to mechanical strain in human scleral fibroblasts. Exp Eye Res 2004;78:275-84

69 Quigley HA, Nickells RW, Kerrigan LA, et al. Retinal ganglion cell death in experimental glaucoma and after axotomy occurs by apoptosis. Invest Ophthalmol Vis Sci 1995;36:774.

70 Kerrigan LA, Zack DJ, Quigley HA, et al. TUNEL-positive ganglion cells in human primary open-angle glaucoma. Arch Ophthalmol 1997; 115:1031-5.

71 Okisaka S, Murakami A, Mizukawa A, et al. Apoptosis in retinal ganglion cell decrease in human glaucomatous eyes. Jpn J Ophthalmol 1997;41:84-8

72 Agar A, Yip SS, Hill MA, et al. Pressure related apoptosis in neuronal cell lines, J Neurosci Res 2000;60:495-503.

73 Agar A, Yip SS, Hill MA, et al. Retinal ganglion cell line apoptosis in a hydrostatic pressure model for chronic glaucoma[ARVO abstract]. Invest Ophthalmol Vis Sci 2001;42:S25. 
74 Dreyer EB, Zurakowski D, Schumer RA, et al. Elevated glutamate levels in the vitreous body of humans and monkeys with glaucoma. Arch Ophthalmol 1996; 1 14:299-305.

75 Vorwerk CK, Naskar R, Schuettauf F, et al. Depression of retinal glutamate transporter function leads to elevated intravitreal glutamate levels and ganglion cell death. Invest Ophthalmol Vis Sci 2000;41:3615-21.

76 Pease ME, McKinnon SJ. Quigley HA, et al. Obstructed axonal transport of BDNF and its receptor TrkB in experimental glaucoma. Invest Ophthalmol Vis Sci 2000;41:764-74.

77 Wax MB. Is there a role for the immune system in glaucomatous optic neuropathy? Curr Opin Ophthalmol 2000;11:145-50.

78 Neufeld AH. Nitric oxide: a potential mediator of retinal ganglion cell damage in glaucoma. Surv Ophthamol 1999;43:S129-35.

79 Anderson DR, Hendrickson A. Effect of intraocular pressure on rapid axoplasmic transport in monkey optic nerve. Invest Ophthalmol 1974;13:771-83

80 Minckler DS, Bunt AH, Johanson GW. Orthograde and retrograde axoplasmic transport during acute ocular hypertension in the monkey. Invest Ophthalmol Vis Sci 1977; 16:426-41.

81 Quigley HA, Addicks EM, Green WR. Optic nerve damage in human glaucoma. II. The site of injury and susceptibility to damage. Arch Ophthalmol 1981;99:635-49.

82 Quigley HA, Hohman RM Addicks EM, et al. Morphologic changes in the lamina cribrosa correlated with neural loss in open-angle glaucoma $\mathrm{Am} J$ Ophthalmol 1983;95:673-91.

83 Pederson JE, Gaasterland DE. Laser-induced primate glaucoma. I. Progression of cupping, Arch Ophthalmol, 1984;102:1689-92.

84 Minckler DS, Tso MO, Zimmerman LE. A light microscopic, autoradiographic study of axoplasmic transport in the optic nerve head during ocular hypotony, increased intraocular pressure, and papilledema. Am J Ophthalmol 1976;82:741-57

85 Quigley HA, Anderson DR. Distribution of axonal transport blockade by acute intraocular pressure elevation in the primate optic nerve head. Invest Ophthalmol Vis Sci 1977;16:640-4.

86 Coroneo MT, Li S, Agar A, et al. Pressure related apoptosis in human and neuronal cell lines. Invest Ophthalmol Vis Sci 2001;42:S23.

87 Tanihara H, Hangai M, Sawaguchi S, et al. Up-regulation of glial fibrillary acidic protein in the retina of primate eyes with experimental glaucoma. Arch Ophthalmol 1997;115:752-6.

88 Tezel G, Wax MB. Inhibition of caspase activity in retinal cell apoptosis induced by various stimuli in vitro. Invest Ophthalmol Vis Sci 1999:40:2660-7.

89 Coroneo MT, Li S, Agar A, et al. The two pore domain mechano-gated K+ channel opener arachidonic acid induces apoptosis in Rgc5 and differentiated Pc12 neuronal cell lines [abstract]. Invest Ophthalmol Vis Sci, 2002;43;ARVO E-Abstract 752..
90 Tumminia SJ, Mitton KP, Arora J, et al. Mechanical stretch alters the actin cytoskeleton network and signal transduction in human trabecular meshwork cells. Invest Ophthalmol Vis Sci 1998;39:1361.

91 Gasull X, Ferrer E, Llobet A, et al. Cell membrane stretch modulates the highconductance Ca2+-activated $\mathrm{K}+$ channel in bovine trabecular meshwork cells. Invest Ophthalmol Vis Sci 2003;44:706-14.

92 Wax MB, Tezel G, Kobayashi S, et al. Responses of different cell lines from ocular tissues to elevated hydrostatic pressure. Br J Ophthalmol 2000;84:423-8.

93 Gonzalez P, Epstein DL, Borras T. Characterisation of gene expression in human trabecular meshwork using single pass sequencing of 1060 clones. Invest Ophthalmol Vis Sci 2000;41:3678-93.

94 Mitton KP, Tumminia SJ, Arora J, et al. Transient loss of alpha B-crystallin: an early cellular response to mechanical stretch. Biochem Biophys Res Commun 1997;235:69-73.

95 Wang N, Chintala SK, Fini ME, et al. Ultrasound activates the TM ELAM-1/ IL-1/NF-kB response: a potential mechanism for intraocular pressure reduction after phacoemulsification. Invest Ophthalmol Vis Sci 2003;44:1977-81.

96 Bradley JMB, Kelley MJ, Zhu X-H, et al. Effects of mechanical stretching on trabecular matrix metalloproteinases. Invest Ophthalmol Vis Sci 2001;42:1505-13.

97 Tamm ER, Flugel C, Stefani FH, et al. Nerve endings with structural characteristics of mechanoreceptors in the human scleral spur. Invest Ophthalmol Vis Sci 1994;35:1157-66.

98 Booth A, Nguyen T, Polansky J. TIGR and stretch in the trabecular meshwork (letter). Invest Ophthalmol Vis Sci 1999;39:1888-9.

99 Borras T, Rowlette LL, Tamm ER, et al. Effects of elevated intraocular pressure on oufflow facility and TIGR/MYOC expression in perfused human anterior segments. Invest Ophthalmol Vis Sci 2002;43:33-40.

100 Tian B, Kaufman PL, Volberg T, et al. H-7 disrupts the actin cytoskeleton and increases outflow facility. Arch Ophthalmol 1998;1 16:633-43.

101 Peterson JA, Tian B, Bershadsky AD, et al. Latrunculin-A increases outflow facility in the monkey. Invest Ophthalmol Vis Sci 1999;40:931-41.

102 Tian B, Geiger B, Epstein DL, et al. Cytoskeletal involvement in the regulation of aqueous humor oufflow. Invest Ophthalmol Vis Sci 2000;41:619-23.

103 Bradley JMB, Kelley MJ, Zhu XH, et al. Effects of mechanical stretching on trabecular matrix metalloproteinases. Invest Ophthalmol Vis Sci 2001;42:1505-13.

104 WuDunn D. The effect of mechanical strain on matrix metalloproteinase production by bovine trabecular meshwork cells. Curr Eye Res 2001;22:394-7.

105 Bradley JM, Kelley M, Rose A, et al. Signaling pathways used in trabecular matrix metalloproteinase response to mechanical stretch. Invest Ophthalmol Vis Sci 2003;44:5174-81 